\author{
M. M. Sulphey, \\ Ph.D., Prince Sattam Bin Abdulaziz University, Saudi Arabia \\ M. Naushad, \\ Ph.D., Prince Sattam Bin Abdulaziz University, Saudi Arabia
}

\title{
THE POSITION OF INTELLECTUAL CAPITAL AMONG SAUDI BANKS
}

Abstract. All intangible assets and various human-centred and the intellectual property rights (IPR) of organizations are considered as Intellectual Capital (IC). It includes all nonmonetary and nonphysical resources that are fully or partially controlled by the organization and contribute to the organization's value creation. Since conventional factors of production are increasingly being replaced by intellectual assets, IC is now being increasingly recognized as the most valuable resource, which can provide the required impetus to take on the competition. Through appropriate management of $I C$, it is possible to enhance the earning capability, sustain the value and help the achievement of organizational goals. Organisations that manage IC would acquire the required competitive advantage and superior business performance in the current volatile and uncertain market. This study was conducted to investigate the position of IC of Saudi banks. Empirical evidence exists to suggest that efficient utilization of IC can contribute towards the success of the banking industry. Objectives of the study included finding the value of IC of the Saudi banking industry and examine the performance of Islamic banks. Two regression models were used to achieve the objectives of the study. The models examined the relationships between Return on equity (ROE) and Return on total assets (ROA) and the aggregate measure of IC. It also examined the different components like Human capital efficiency (HCE), the Capital employed efficiency (CEE), and Structural capital efficiency (SCE). The present study has thus helped in presenting some interesting findings of the IC of Saudi banks. It was observed that Saudi banks are fairly efficient and has generated the required value from the component of Human capital (HC) than other capital elements. Drastic improvement was evident during recent years, reflecting the cues about the stability evident globally in the industry. Overall it can be concluded that Saudi banks, especially the Shariah-compliant ones, are efficient in generating value from its IC. A comparison between Saudi banks, as well as Islamic banks and those in other countries where banking operations are not done as per Shari'ah rules, is suggested as it is sure to bring in interesting results.

Keywords: intellectual capital, structural capital, banking industry, Saudi Arabia.

Introduction. The present VUCA markets have thrust upon organisations the need to be agile and dextrous to take on the competition. With technology and other conventional factors of production being universally available and accessible to all, organisations are on the lookout for a competitive edge that can outsmart the others in the market. Further, in almost all industries, the conventional factors of production are replaced by intellectual assets. Due to this $\mathrm{IC}$ is now being increasingly recognized as the most valuable (and if not the only) resource, that can provide the required impetus to outsmart competitors. It is one aspect that can contribute towards improving organizational efficiency and the badly required sustainable competitive advantage and value addition (Barney, 1991; Reed, Lubatkin, and Srinivasan, 2006). This is because; IC is one aspect that is incapable of being imitated or substituted.

Though giving the due importance to identifying and measuring intangible assets is acknowledged by most business organisations, the currently followed traditional accounting practices still focuses mostly on tangible assets. The focus of the majority of the organisations is only on a few intangible assets belonging to the intellectual property (IP) like patents, copyrights, trademarks, etc. Most organisations fail to measure, evaluate and account for their intangible IC assets. This often results in the inefficient allocation of scarce resources and even mismanagement; calling for specific standards for measurement and reporting of IC. Many service industries like Information technology, banking, insurance, consultancies, etc. thrive merely due to their IC. Banking is an industry that has the unique characteristic of possessing a high IC base (Sveiby, 1997). Banks of Saudi Arabia are unique as the majority of them conduct business

Cite as: Sulphey, M. M., Naushad, M. (2019). The Position of Intellectual Capital among Saudi Banks. Marketing and Management of Innovations, 4, 11-21. http://doi.org/10.21272/mmi.2019.4-01 
as per the tenets of Islam. This uniqueness of Saudi banks has prompted the authors to examine the position of IC of the country.

Literature Review. Though the term «intellectual capital» was first coined way back in 1969 by John Kenneth Galbraith (Feiwal, 1975); references to this can be seen as early as 1836 when N. Senior wrote, "The intellectual and moral capital of Great Britain far exceeds all the material capital, not only in importance but in productiveness» (Senior, 1836). Later references can be seen in the 1930s. For instance, J. Robinson and Edward Chamberlin called for a «resourced based accounting» (Chamberlin 1962). Taking a cue from these works, Penrose (1959) developed an approach for resource-based accounting and published it as a book «The theory of growth».

The concept was further enriched by Teece (1986) upon the publication of the work related to Human Capital and providing due recognition and value to the aspect of innovation. However, the concept of IC started to gain attention only in the 1990s, wherein a number a publication emerged (for instance, Barney, 1991; Edvinsson \& Malone, 1997; Stewart, 1997). These works helped in finding out varied aspects and facets of $I C$ and succeeded in enriching the concept. Though the concept has been defined and redefined by many management experts and researchers, a clear definition of IC is still elusive. It would now be imperative to discuss the definitions of IC.

Defining IC: Though there is no universally accepted definition of IC, as it is a tough proposition to define it, many management researchers and experts have presented their views about the concept. Many management researchers have referred to $\mathrm{IC}$ as the difference between the market value and book value, or in other sense «the hidden value of firms». For instance, as early as in 1969, Galbraith defined IC as the «difference of an organization's market value and book value». Itami \& Roehl (1987) described it as: «intangible assets comprising of technology, goodwill and brand name, organization culture and information about the customer that can contribute to a firm's competitive power».

Adding many other dimensions and providing a comprehensive definition, Barney (1991) stated it to be a «firm's resources including its assets, capabilities, organizational processes, firm attributes and information knowledge that collectively contribute to improved organizational efficiency and sustainable competitive advantage». Brooking (1996) considered IC to include all combined intangible assets of the organisation, which enables it to function. This includes the market, and various human-centred and intellectual property rights. Stewart (1997) provided a short and crispy definition when he defined IC as «packaged useful knowledge».

He listed the various organizational processes, technologies, patents, unique skills of employees, and accumulated information about customers, suppliers and stakeholders as IC. Edvinsson (1997) identified IC as: "The possession of knowledge, applied experience, organisational technology, customer relationships, and professional skills that provide... a competitive edge in the market». According to Sullivan (2000), IC is: «that knowledge that can be converted into future profits and includes resources such as ideas, technologies, processes, designs and informatics programmes».

Bontis, Crossan \& Hulland (2002) considered it to «represents the stock of knowledge that exists in an organization at a particular point in time». Martınez-Torres (2006) stated it to include: «intangible assets of an organization that are not recorded in financial statements, but which may constitute $80 \%$ of the market value of the organization».

In similar lines, Roos, Roos, Dragonetti \& Edvinsson (2007) defined IC as «all nonmonetary and nonphysical resources that are fully or partially controlled by the organization and contribute to the organization's value creation». All these discussions present the case of IC to be knowledge-based and intangible, which is "captured in an identifiable form and is useful for the organizations that possess it». While few authors consider IC as a resource that creates value or generates a competitive advantage, others discuss it in terms of market-orientation. Most of them agree that it is intangible and invisible. Further 
analysis of the definitions brings out the point that those who have attempted to define the concept seems to diverge widely in their propositions.

Taxonomy of IC: Numerous efforts have been made by management experts and researchers to identify the taxonomy and list down the components of the IC. A few such efforts are presented in Table 1.

Table 1. Taxonomy of IC

\begin{tabular}{|c|c|c|}
\hline № & Authors & Components \\
\hline 1 & Brooking (1996) & $\begin{array}{r}\text { Market assets / Intellectual property assets / } \\
\text { Human-centred assets / Infrastructure assets }\end{array}$ \\
\hline 2 & Edvinsson \& Malone (1997) & Human capital / Structural capital / Customer capital \\
\hline 3 & Pulic (1998); Pulic \& Bornemann (1999) & Physical capital / Human capital and Structural capital \\
\hline 4 & Mouritsen (1998) & Human capital / Organisational capital / Customer capital \\
\hline 5 & Meer-Kooistra \& Zijstra (2001) & $\begin{array}{c}\text { Human capital / Customer capital / } \\
\text { Process capital / Innovation capital }\end{array}$ \\
\hline 6 & Fincham \& Roslender (2003) & $\begin{array}{c}\text { Human abilities / Internal organisational structure, } \\
\text { External structure / Innovative capabilities }\end{array}$ \\
\hline 7 & Leliaert et al (2003) - 4 Leaf Model & $\begin{array}{c}\text { Human capital / Customer capital / } \\
\text { Structural capital / Strategic alliance capital }\end{array}$ \\
\hline 8 & Cohen (2005) & Identifiable capital (IPRs) / Not identifiable (for instance goodwill) \\
\hline
\end{tabular}

Source: compiled by authors.

The components identified by Edvinsson \& Malone (1997) and few others are discussed in detail as it has a special bearing on the present study. The details of these are presented in Table 2.

Table 2. Components of IC

\begin{tabular}{|c|c|c|}
\hline № & Components & Description \\
\hline 1 & Human capital & $\begin{array}{l}\text { This capital, as the name denotes, is processed by human beings and is not owned by } \\
\text { organizations. Examples of this capital include knowledge, skills, and abilities of the } \\
\text { employees. It also includes creativity and innovation of the human resource. It can be } \\
\text { considered as the combined human capability of the organization that can solve various } \\
\text { business problems. This capital leaves an organization when people leave. This capital } \\
\text { considers how effectively an organization uses its human resources and can be measured in } \\
\text { terms of creativity and innovation (Sulphey, 2014). }\end{array}$ \\
\hline 2 & $\begin{array}{c}\text { Structural } \\
\text { capital }\end{array}$ & $\begin{array}{l}\text { This capital supports and enables human resource/capital in their function. Structural capital } \\
\text { is owned and remains with the organization, irrespective of whether people leave or not. } \\
\text { Examples of this capital include buildings, processes, hardware, organizational image, IPR, } \\
\text { proprietary databases, etc. Structural capital is again classified into the following. } \\
\text { 1. Organizational capital: This is the philosophy of the organization and the various systems } \\
\text { required for leveraging its capability. } \\
\text { 2. Process capital: The various techniques, procedures, and programs that facilitate and } \\
\text { enhance the delivery of goods and services are included in this. } \\
\text { 3. Innovation capital: These are the IPR like copyrights, trademarks, patents; and other } \\
\text { intangible assets. Intangible assets include the other talents through which an organization } \\
\text { progresses. }\end{array}$ \\
\hline 3 & $\begin{array}{c}\text { Customer } \\
\text { capital }\end{array}$ & $\begin{array}{l}\text { Customer capital includes the strength and loyalty of the customer of the organisation. This } \\
\text { could result in a host of aspects like customer satisfaction, repeat businesses, financial well- } \\
\text { being, etc. Customer capital can increase the organization's worth. This capital is distinct } \\
\text { from the others as it can create relationships within or outside the organization. }\end{array}$ \\
\hline
\end{tabular}

Source: compiled by authors. 
This classification seems to be the most basic one, and this has been followed by many other experts in the field.

A different perspective was presented by Brooking (1996), wherein IC is considered to comprise of four types of assets. It presents a slightly different picture from that of Edvinsson \& Malone (1997):

1. Market assets: This consists of aspects like the various brands owned by the organisation, the different distribution channels, collaborations with stakeholders and the customers.

2. Intellectual property assets: Examples are patents, copyrights, trademarks, and so on.

3. Human-centred assets: Education of the employees and work-related knowledge and competencies of human resources are included in this.

4. Infrastructure assets: These are the different management processes, and systems like IT, financial, networking, etc.

Yet another one, the Value-Added Intellectual Coefficient (VAIC) measures the extent to which value addition takes place based on various intellectual resources (Pulic, 1998; Pulic \& Bornemann, 1999). There are three major components, the sum of which forms the value of VAIC. The components are similar to those proposed by Edvinsson \& Malone (1997) and presented in Table 1. The components include physical capital, human capital and structural capital. The sum of these three aggregates is the value of VAIC.

Uses of IC: Proper management of IC is an important step in the building of a wealth-enhancing and value-sustaining organization (Edvinsson \& Malone, 1997; Sulphey \& Alkahtani, 2017). Similarly, Brooking (1996) opines that proper management of IC would help organizations to achieve their goals. It can provide a competitive advantage to companies and the resultant superior business performance. Due to this, IC is regarded as the most asset at the disposal of any company (Fincham \& Roslender, 2003). IC is also found to play a crucial role in increasing the market value of a firm. In «efficient markets», investors often tend to attach a higher value to those firms that are having greater IC (Firer \& Williams, 2003; RiahiBelkaoui, 2003). However, the biggest problem concerning IC is that it is difficult to identify them separately. Further, IC being intangible can only be sold in association with others and not separately, as they are inseparable (Scicluna, 1994). A similar view is shared by Lev (2007) when he stated that IC is difficult to assess because of their «partial excludability, high risk and not-tradability».

Though IC has immense benefits in terms of providing a competitive advantage, it is normally not accounted for and is untraded in any market. If this is to happen, and to manage the intangibles of the IC, it should first be measured and reported. Evidence shows that measurement and reporting of the intangibles resulted in a reduction of cost of capital (Edvinsson, 1997).

Measuring IC: Several models like Balanced Scorecard (Kaplan \& Norton, 1996), Brooking Model (Brooking, 1996; Brooking, Board \& Jones, 1997) Skandia's IC Navigator (Edvinsson \& Malone, 1997), Intellectual Capital Services' IC-IndexTM (Roos \& Roos, 1997), Value Added Intellectual Coefficient (VAIC) (Pulic, 1998; Pulic \& Bornemann, 1999); etc. that facilitate measurement of IC have been developed in the late 1990s. These models succeeded in highlighting the strategic importance of the IC. The models also helped in identifying IC as an ideal resource that can achieve a sustainable competitive advantage for the organisation. The VAIC which measures both tangible and intangible assets is very popular (Williams 2001) and is considered as an indirect measure of value-added (VA) (Pulic, 1998). It has recently been empirically proved that if investors place different values for the three components, viz. physical, human and structural capitals; then it will have better and greater explanatory power (Tandon, Purohit \& Tandon, 2016).

There is a definite need to measure and value IC. Now there are multitudes of measures that facilitate the valuation of IC. Tan, et al, (2007) classified the various techniques it into monitory and non-monitory. The various measures of IC as classified by Tan et al, (2007) are presented in Table 3. 
Table 3. Measures of IC

\begin{tabular}{|c|c|c|}
\hline Classification & Authors & Measure \\
\hline \multirow{8}{*}{$\begin{array}{c}\text { Non-Monetary } \\
\text { Valuation } \\
\text { techniques }\end{array}$} & Kaplan \& Norton (1992) & Balance Scorecard \\
\hline & Brooking (1996) & Technology Broker method \\
\hline & Edvinssion \& Malone (1997) & Skandia IC Report method \\
\hline & Roos et al. (1997) & IC-Index \\
\hline & Sveiby's (1997) & Intangible Asset Monitor approach \\
\hline & Joia $(2000)$ & Heuristic Frame \\
\hline & Vanderkaay's (2000) & Vital Sign Scorecard \\
\hline & Barsky and Marchant, 2000 & Ernst \& Young Model \\
\hline \multirow{6}{*}{$\begin{array}{l}\text { Monetary } \\
\text { valuation } \\
\text { techniques }\end{array}$} & Bontis, Dragonetti, Jacobsen, \& Roos (1999) & EVA and MVA model \\
\hline & Various authors & Market-to-Book Value model \\
\hline & Luthy (1998) & Tobin's q method \\
\hline & Public's $(1998,2000)$ & VAIC Model \\
\hline & Dzinkowski (2000) & Calculated intangible value \\
\hline & Lev and Feng (2001) & Knowledge Capital Earnings model \\
\hline \multirow{4}{*}{$\begin{array}{l}\text { Other } \\
\text { techniques }\end{array}$} & Johanson and Grojer (1998) & HR Costing \& Accounting \\
\hline & Nash (1998) & Accounting for the Future \\
\hline & McLean (1999) & Total Value Creation \\
\hline & $\begin{array}{l}\text { Andriessen and Tissen (2000) } \\
\text { Andriessen (2001) }\end{array}$ & $\begin{array}{l}\text { The Value Explorer and Weightless } \\
\text { Weights }\end{array}$ \\
\hline
\end{tabular}

Source: Tan, et al, (2007).

Selection of an appropriate measure from these multitudes of techniques is indeed challenging for any researcher. However, it gives the researcher the option and freedom for choosing from a host of alternatives, based on the needs and requirements of the situation.

Empirical studies. Ballow, Thomas \& Roos (2004) found that though a brute majority (94\%) of the senior executives are apprised of the definite need and importance of IC, only around $5 \%$ opined that there is no foolproof system in their organization that can monitor this invaluable asset. The biggest issue of identifying and measuring $\mathrm{IC}$ is the heterogeneity of this important resource. To identify and analyse IC there is a definite requirement to split it into its components and examine them separately.

Studies concerning the relationship between IC and financial performance have provided mixed results. For instance, while Riahi-Belkaoui (2003) found a positive relationship between the two, Firer \& Williams (2003) did not find any relationship between the two. The association of IC and profitability was the matter of examination by Chen, Cheng \& Hwang (2005). The study observed a significant impact of IC on the profitability of firms. A similar finding was found concerning productivity by Patton (2007), wherein productivity was found to be dependent upon IC rather than the physical assets of the firm. Substantial evidence exists to prove a significant positive relationship between the value of $\mathrm{IC}$ and shareholder value (Anand \& Khanna, 2000; Fornell, et al, 2006; Gruca \& Rego, 2003; Nakamura, 2001; Suarez, 2002).

IC in Banking Industry: A review of the literature shows that quite a few empirical examinations have been undertaken across the world in the area of IC. The IC of various industries including banking has been undertaken. Enthusiasm has been witnessed in various parts of the world for identifying the $\mathrm{IC}$ of the banking industry. This because the success of the banking industry is mostly based on the efficient utilization of IC (Ahuja \& Ahuja, 2012). Further, the prompt delivery of quality services to the bank customers is dependent on the investments and management efficient management made in IC (Goh, 2005).

Realizing this, several studies have been undertaken in this area across the globe. Identification of IC in banks has been done in Canada in the late 1990s when a study was undertaken at the Royal Bank of 
Canada (Lynn, 1998). Other studies conducted in banking industry include those for British banks by ElBannany (2008), South African banks by Firer and Williams (2003), Australian banks by Joshi, Cahill \& Sidhu (2010), Iranian banks by Mehralian, et al. (2012) and for Malaysian banks by Goh (2005). A few studies have also been conducted in the Gulf Co-operation Countries (GCC). Some of them include that of Al-Musali and Ku (2011) in GCC banks, Salam, Al-Qaheri \& Al-Khayyat (2011) in Kuwaiti banks; and $\mathrm{Ku}$ and Karem (2011) in Bahraini banks. However, studies about IC, especially banking, are very few in Saudi Arabia. A study by Al-Musali \& Imsail (2014) measured the IC of commercial banks in Saudi Arabia. The study used the VAIC Model (Pulic, 1998; 2000) to measure the IC of Saudi Banks from 2008 to 2010. It also examined if IC and its components influenced the financial performance measures like ROA and ROE. The results showed that that IC performance of Saudi banks is «low and it is positively associated with bank financial performance indicators».

Towards diversifying the economy, the Saudi government has been providing due importance to the banking industry. Further, because most of the banks in Saudi Arabia is conducted as per the tenets of Islam, it would be worthwhile to examine the IC of Saudi banks. The present study attempts to fill this gap in management literature. Based on the review of the related literature, the following objectives are set out for the study:

- to find out the value of IC of the Saudi banking industry;

- to examine if the performance of Islamic banks were different in terms of IC against conventional banks.

Methodology and research methods. To examine the complex relationship among the components of IC and financial performances of Saudi Arabian banks the following two regression models were used:

Model 1.1: $R O E=\beta i+\beta 1 V A I C+\beta 2 S I Z E+e$

Model 1.2: $R O E=\beta i+\beta 1 H C E+\beta 2 S C E+\beta 3 C E E+\beta 4 S I Z E+e$

Model 2.1: $R O A=\beta i+\beta 1 V A I C+\beta 2 S I Z E+e$

Model 2.2: $R O A=\beta i+\beta 1 H C E+\beta 2 S C E+\beta 3 C E E+\beta 4 S I Z E+e$

Model 1 and 2 examined the relationships between ROE and ROA and the aggregate measure of IC VAIC. It also examined the different components, viz., Human capital efficiency (HCE), the Capital employed efficiency (CEE), and Structural capital efficiency (SCE).

Collection of Data: Data for the study was collected from the Balance sheet and Income statement for the four years from 2013. The sample consists of all the 12 Saudi Arabian banks that were listed in Tadawul, the stock exchange of the country. Altogether there were 48 observations from the 12 banks. Of the 12, four of them are Islamic Banks and they conduct business as per the advice and tenets of the Shari'ah or Prophetic instructions. Shari'ah bans the conduct of businesses that are against Islamic principles of justice and equity. These banks do not conduct business based on the popular concept of usury or interest.

The measure used: Consistent with previous studies, measuring of IC performance was done using Value Added Intellectual Coefficient (VAIC) method, as provided by Pulic (1998, 2000). VAIC can be computed using the formula:

VAIC $=$ CEE + HCE + SCE

where: $C E E$ is Capital Employed Efficiency indicates value creation as a result of all material and financial assets invested. CEE is computed by dividing the Value Added (VA) by Capital Employed (CE); $\mathrm{HCE}$ is Human Capital Efficiency is computed by dividing VA by Human Capital (HC). HC considered as an investment and indicates Salaries \& Employees benefits; SCE or Structural Capital Efficiency is measured by dividing SC by VA. SC is the difference of VA and $\mathrm{HC}$. 
As in earlier studies (Al-Musali and Ismail, 2014), the current study used two proxies to measure performance - Return on equity (ROE) and Return on total assets (ROA). ROA is Total income, which includes net interest and non-interest income, above total assets; whereas ROE reflects Total income over the book value of Shareholders Equity. In the regression model, Bank size is the only control variable that minimizes its interaction with dependent variables.

Results. Table 4 displays the aggregate performance of IC VAIC, and its three major components, viz., HCE, CEE and SCE for the study period (from 2013 to 2016). From the Table, it can be observed that the present combined VAIC for Saudi banks stands at 4.154. This denotes an increase from 3.646 as presented in an earlier study by Al-Musali \& Ismail (2014) for the period from 2008 to 2010.

Table 4. Aggregate IC performance of Saudi Arabian Banks

\begin{tabular}{|c|c|c|}
\hline Years & Item & Coefficient \\
\hline \multirow{4}{*}{ Year 1 } & CEE & 0.031 \\
\cline { 2 - 3 } & HCE & 3.606 \\
\cline { 2 - 3 } & SCE & 0.698 \\
\hline \multirow{4}{*}{ Year 2 } & VAIC & 4.336 \\
\cline { 2 - 3 } & CEE & 0.032 \\
\cline { 2 - 3 } & HCE & 3.482 \\
\cline { 2 - 3 } & SCE & 0.694 \\
\hline \multirow{4}{*}{ Year 3 } & VAIC & 4.209 \\
\cline { 2 - 3 } & CEE & 0.030 \\
\cline { 2 - 3 } & HCE & 3.203 \\
\cline { 2 - 3 } & SCE & 0.663 \\
\hline \multirow{4}{*}{ Year 4 } & VAIC & 3.896 \\
\cline { 2 - 3 } & CEE & 0.031 \\
\cline { 2 - 3 } & HCE & 3.457 \\
\cline { 2 - 3 } & SCE & 0.689 \\
\cline { 2 - 3 } & VAIC & 4.177 \\
\hline \multirow{4}{*}{ Overall } & CEE & 0.031 \\
\cline { 2 - 3 } & HCE & 3.437 \\
\cline { 2 - 3 } & SCE & 0.686 \\
\cline { 2 - 3 } & VAIC & 4.154 \\
\hline
\end{tabular}

Sources: developed by the authors.

It can be observed that a drastic improvement was evident during the later years, reflecting the cues from the stability evident globally in the industry. However, during the period, the banks in Saudi Arabia were generally more efficient in generating value from its $\mathrm{HC}$ rather than $\mathrm{CE}$ and $\mathrm{SC}$. This in line with the findings a few earlier studies (Riahi-Belkaoui, 2003; Chen, Cheng \& Hwang, 2005). Other studies which showed that IC is associated with performance include that of Fornell, et al, (2006); Gruca \& Rego (2003); Nakamura (2001) \& Suarez (2002). However, most of these studies were done among non-banking companies.

To conduct an in-depth analysis the present study examined the interrelationships among the different components of IC and the financial performance. For these two regression models were employed. The result is presented in Table 5 .

The results present a mixed picture with no significance in ROE (Model 1) and significance concerning ROA (Model 2). This reveals that no relationship exists between IC and financial performance (Model 1.1). However, it is observed that CEE (Model 1.2) was highly significant. In Model 2 all the variables were found to be significant. 
Table 5. Regression results of Saudi Arabian Banks

\begin{tabular}{|c|c|c|c|c|}
\hline \multirow{2}{*}{ Indicator \& Control variables } & \multicolumn{2}{|c|}{ ROE } & \multicolumn{2}{|c|}{ ROA } \\
\hline & Model 1.1 & Model 1.2 & Model 2.1 & Model 2.2 \\
\hline VAIC & $\begin{array}{c}1.026 \# \\
(.310)\end{array}$ & & $\begin{array}{c}4.49^{* \star \star} \\
(.000)\end{array}$ & 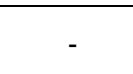 \\
\hline CEE & 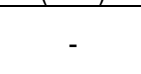 & $\begin{array}{c}3.922^{* * *} \\
(.000)\end{array}$ & 1 & $\begin{array}{c}18.003^{* * *} \\
(.000)\end{array}$ \\
\hline HCE & - & $\begin{array}{l}0.496 \# \\
(.622)\end{array}$ & - & $\begin{array}{c}2.017^{* *} \\
(.050)\end{array}$ \\
\hline SCE & - & $\begin{array}{l}-0.045 \\
(.964)\end{array}$ & - & $\begin{array}{c}2.917^{* * *} \\
(.006)\end{array}$ \\
\hline Bank Size & $\begin{array}{l}1.745^{*} \\
(0.088)\end{array}$ & $\begin{array}{c}2.028^{\star *} \\
(.049) \\
\end{array}$ & $\begin{array}{l}1.27 \# \\
(.211) \\
\end{array}$ & $\begin{array}{c}.091^{* * *} \\
(.003)\end{array}$ \\
\hline
\end{tabular}

* Significant at $10 \% \quad{ }^{* *}$ Significant at $5 \% \quad{ }^{* * *}$ Significant at $1 \% \quad$ \# Not significant

Source: developed by authors.

As regards the Bank size, both the models were significant. This presents a picture that the size of the banking institution has a direct impact on their respective performance levels (Table 6).

Table 6. Regression results of Saudi Arabian Islamic Banks

\begin{tabular}{|c|c|c|c|c|}
\hline \multirow{2}{*}{ Indicator \& Control variables } & \multicolumn{2}{|c|}{ ROE } & \multicolumn{2}{|c|}{ ROA } \\
\hline & Model 1.1 & Model 1.2 & Model 2.1 & Model 2.2 \\
\hline VAIC & $\begin{array}{c}5.299^{* * *} \\
(.000)\end{array}$ & - & $\begin{array}{c}9.230^{* * *} \\
(.000)\end{array}$ & - \\
\hline CEE & - & $\begin{array}{l}0.130 \# \\
(.897)\end{array}$ & - & $\begin{array}{c}12.155^{\star \star *} \\
(.000)\end{array}$ \\
\hline HCE & - & $\begin{array}{l}0.499 \# \\
(.621)\end{array}$ & - & $\begin{array}{c}2.101^{* *} \\
(.042)\end{array}$ \\
\hline SCE & - & $\begin{array}{c}2.164^{* *} \\
(.036)\end{array}$ & - & $\begin{array}{c}4.041^{* * *} \\
(.000)\end{array}$ \\
\hline Bank Size & $\begin{array}{l}-0.911 \# \\
(0.367)\end{array}$ & $\begin{array}{c}-1.569 \# \\
(.124)\end{array}$ & $\begin{array}{c}-1.540 \# \\
(.131)\end{array}$ & $\begin{array}{l}0.522 \# \\
(.604)\end{array}$ \\
\hline Dummy (D1) & $\begin{array}{c}6.711^{* * *} \\
(.000)\end{array}$ & $\begin{array}{c}4.980^{* * *} \\
(.000)\end{array}$ & $\begin{array}{c}6.824^{* * *} \\
(.000)\end{array}$ & $\begin{array}{c}2.772^{\star \star \star} \\
(.000)\end{array}$ \\
\hline
\end{tabular}

* Significant at $10 \% \quad{ }^{* *}$ Significant at $5 \%{ }^{* * *}$ Significant at $1 \% \quad$ \# Not significant

Source: developed by authors.

It was also an objective of the study to examine if the performance of Islamic banks were different in terms of IC concerning conventional banks. The analysis revealed that Islamic banks in Saudi Arabia are having a better position concerning $I C$ in terms of performance for the entire period of study (Table 5). A deeper analysis of the components of VAIC (Model 1) showed that only SCE is significant. This shows that the infrastructure assets like various management processes and systems like IT, financial, networking, etc. were found to be significantly influencing the performance of these banks.

Concerning ROA, all three components of VAIC were significant. While SCE and EEC were highly significant at $1 \%$, HCE was significant at $5 \%$. This denotes that as compared to conventional banks in Saudi Arabia, Islamic Banks performed better concerning IC. However, it was observed that the size of the Islamic Banks was not a determining factor.

Conclusions. As state earlier, the success of the banking industry is based mostly on the efficient utilization of IC. Appropriate investments in and proper management of IC will go a long way in facilitating prompt delivery of quality services to customers and other stakeholders. The study has found that Saudi 
banks are efficient and has generated the required value from their $\mathrm{HC}$ rather than other capital elements. The most significant and encouraging finding of this study is that as against the conventional banks of Saudi Arabia, Islamic Banks which conduct business as per Shari'ah rules are found to have performed better concerning IC.

It would be enlightening and highly informative if a comparison is made between Saudi banks, as well as Islamic banks, which are run as per Islamic tenets with that of banks in other countries where banking operations are not done as per Shari'ah rules. It is expected that future researchers will be directed towards this direction. The authors will be highly obliged if more works are undertaken in this highly challenging area.

Author Contributions. Conceptualization, writing-original draft preparation; writing-review and editing, S. M. M.; review and resources, project administration, M. N.

Funding. This research received no external funding.

\section{References}

Al-Musali, M. A. \& Imsail, K. N. I. K. (2014). Intellectual capital and its effect on financial performance of banks: Evidence from Saudi Arabia, Procedia - Social and Behavioral Sciences, 164, 201 - 207. doi: 10.1016/j.sbspro.2014.11.068

Al-Musalli, M. A. \& Ismail, K. N. I. K. (2012). Corporate governance, bank specific characteristics, banking industry characteristics, and intellectual capital performance of banks in Arab gulf cooperation council countries. Asian Academy Management Journal of Accounting \& Finance, 8 (Special issue), 115-135.

Anand, B. N. \& Khanna, T. (2000). Do firms learn to create value? The case of alliances. Strategic Management Journal, 21, 295-315.

Andriessen, D. \& Tissen, R. (2000). Weightless Wealth: Find Your Real Value in a Future of Intangible Assets, Financial Times Prentice-Hall, London.

Andriessen, D. (2001). Weightless wealth: four modifications to standard IC theory. Journal of Intellectual Capital, 2(3) 204-14.

Ballow, J. J., Thomas, R. J., \& Roos, G. (2004). Future value: The $\$ 7$ trillion challenge. Journal of Applied Corporate Finance, 16(1), 71-76.

Barney, J. (1991). Firm resources and sustained competitive advantage. Journal of Management, 17(1), 99-120.

Barsky, N. P. \& Marchant, G. (2000). The most valuable resource - measuring and managing intellectual capital. Strategic Finance, 81(8), 58-62.

Bontis, N., Crossan \& Hulland, J. (2002), Managing an Organizational Learning System by Aligning Stocks and Flows, Journal of Management Studies 39, 437-469.

Bontis, N., Dragonetti, N. C., Jacobsen, K. \& Roos, G. (1999). The knowledge toolbox: a review of the tools available to measure and manage intangible resources. European Management Journal, 17, 391-401.

Brooking, A. (1996). Intellectual capital: Core asset for the third millennium enterprise. New York, NY: International Thomas Business Press.

Brooking, A., Board, P. \& Jones, S. (1997). The Predictive Potential of Intellectual Capital. National Business Conference, Hamilton, Ontario.

Chamberlin, E. H. (1962). The theory of monopolistic competition: A reorientation of the theory of value. 8th Ed., Cambridge Massa.: Harvard University Press.

Chen, M. C., Cheng, S. J., \& Hwang, Y. A. (2005). An empirical investigation of the relationship between intellectual capital and firm's market valuation and financial performance. Journal of Intellectual Capital, 6(2), 159-176.

Cohen J. A. (2005). Intangibles assets. Valuation and Economic benefit., John Wiley \& Sons, New Jersey, USA.

Dzinkowski, R. (2000). The measurement and management of intellectual capital: an introduction. Management Accounting, 72(2), 32-6.

Edvinsson, L. \& Malone, M. S. (1997). Intellectual Capital: Realizing Your Company's True Value by Finding Its Hidden Roots. HarperCollins Publishers, Inc., New York.

Edvinsson, L. (1997). Developing intellectual capital at Skandia. Long Range Planning, 30(3), 320-373.

El-Bannany, M. (2008). A study of determinants of intellectual capital performance in banks: the UK case. Journal of Intellectual Capital, 9(3), 487-498.

Feiwal, G. R. (1975). The intellectual capital of Michael Kalecki-A study in economic theory and policy. Knoxville, TN: The University of Tennessee Press.

Fincham, R \& Roslender, R. (2003). The Management of Intellectual Capital and its Implications for Business Reporting, Edinburg: The Institute of Chartered Accountants of Scotland.

Firer, S., \& Williams, S.M. (2003). Intellectual capital and traditional measures of corporate performance. Journal of Intellectual Capital, 4(3), 348-360. 
Fornell, C., Mithas, S., Morgeson, F. V. \& Krishnan, M. S. (2006). Customer satisfaction and stock prices: high returns, low risk. Journal of Marketing, 70(1), 3-14. 396.

Goh, P. C. (2005). Intellectual capital performance of commercial banks in Malaysia. Journal of Intellectual Capital, 6(3), 385-

Gruca T. F. \& Rego L. L. (2003). Customer satisfaction, cash flow and shareholder value. Marketing Science Institute Working Paper Series, n. 03-002., 3-18.

Itami, H., \& Roehl, T.W. (1987). Mobilizing invisible assets. Cambridge, MA: Harvard University Press.

Johanson, U. \& Grojer, J. E. (1998). Current development in human resource costing and accounting: reality present, researchers absent? Accounting, Auditing \& Accountability Journal, 11(4), 495-504.

Joia, L. A. (2000). Measuring intangible corporate assets linking business strategy with intellectual capital. Journal of Intellectual Capital, 1(1), 68-84.

Joshi, M., Cahill, D., \& Sidhu, J. (2010). Intellectual capital performance in the banking sector: An assessment of Australian owned banks. Journal of Human Resource Costing and Accounting, 14(2), 151-170

Kaplan, R. S. \& Norton, D. P. (1992). The balanced scorecard - measures that drive performance. Harvard Business Review, 70(1) $71-9$

Ku, Ismail, K. N. I., \& Karem, A. M. (2011). Intellectual capital and the financial performance of banks in Bahrain. Journal of

Business Management and Accounting, 1(1), 63-77.

Lev, B. \& Feng, G. (2001). Intangible assets: measurement, drivers, usefulness. New York University, New York, NY.

Lev, B. (2007). Enhancing Shareholder Value Through IP Disclosure. New York University, 2007. Available at

http://pages.stern.nyu.edu/ blev/docs/EnhancingShareholderValueThroughlPDisclosure.pdf

Luthy, D. H. (1998). Intellectual capital and its measurement. Utah State University, Logan, UT. available at: www.bus.osakacu.ac.jp/apira98/archives/htmls/25.htm

Lynn, B. (1998). The management of intellectual capital: the issues and the practice. The Society of Management Accountants of Canada, Hamilton, Ontario.

McLean, R. (1999). Accounting for the creation of value. available at: http://cpri.matrixlinks.ca/tvc/Presentations/ TVCPresent/index.htm

Meer-Kooistra, J. \& Zijlstra, S. M. (2001). Reporting on intellectual capital. Accounting, Auditing and Accountability Journal, 14(4), 456-476.

Mehralian, G., Rajabzadeh, A., Sadeh, M. R., \& Rasekh, H. R. (2012). Intellectual capital and corporate performance in Iranian pharmaceutical industry. Journal of Intellectual Capital, 13(1), 138-158.

Mouritsen, J. (1998). Driving growth: economic value added vs intellectual capital. Management Accounting Research, 9(4), 461-482.

Nakamura L. I. (2001). What is the U.S. gross investment in intangibles? (at least) One trillion dollars a year! Federal Reserve Bank of Philadelphia working paper, 01-15.

Nash, H. H. (1998). Accounting for the future. Prospective Accounting Initiative, available at: http://home.sprintmail.com/humphreynash/indexback.htm

Penrose, E. (1959). The theory of the growth of the firm, Oxford: Blackwell

Pulic, A. (1998). Measuring the performance of intellectual potential in knowledge economy. Available at www.vaicon.net/start.htm

Pulic, A., \& Bornemann, M. (1999). The physical and intellectual capital of Australian banks. Available at www.measuringip.at/Papers/Pubic/Bank/en-bank.html

Riahi-Belkaoui, A. (2003). Intellectual capital and firm performance of US multinational firms: A study of the resource-based and stakeholder views. Journal of Intellectual Capital, 4(2), 215-226.

Roos, G., \& Roos, J. (1997). Measuring your company's intellectual performance. Long Range Planning, 30(3), 413-426.

Roos, J., Roos, G., Dragonetti, N., \& Edvinsson, L., (1997). Intellectual Capital: Navigating in the New Business Landscape. Macmillan.

Salam, A. F., Al-Qaheri, H., \& Al-Khayyat, R. (2011). The intellectual capital performance of Kuwaiti banks: an application of VAIC model. Available online at http://www.SciRP.org/journal/ib

Scicluna, M. (1994). Goodwill: The case for separate intangibles. Accountancy, 113 (1207), 101

Senior, N. (1836). An Outline of the Science of Political Economy, Longman, London in: P. Quintas, P. Lefrere, G. Jones, in Knowledge management: A strategic Agenda, Long Range Planning, 30(3), 386.

Stewart, T. (1997). Intellectual capital: The new wealth of organizations. Doubleday Dell Publishing Group: New York.

Suarez, M. M. V. (2002). Stock market response to the formation of global alliances: evidence from Spanish corporations. European Business Review, 14(6), 401-8.

Sullivan, P.H. (2000). Value-driven intellectual capital: How to convert intangible corporate assets into market value. New York: John Wiley \& Sons, Inc.

Sulphey, M. M. (2014). Behavioural Finance, New Delhi: PHI Learning Pvt. Ltd.

Sulphey, M. M. \& Alkahtani, N. S. (2017). Organizational ambidexterity as a prelude to corporate sustainability, Journal of Security and Sustainability Issues, 7 (2), 335-347. https://doi.org/10.9770/jssi.2017.7.2(13) 
Sveiby, K.E. (1997). The new organizational wealth: Managing \& measuring knowledge-based assets. San Francisco, CA: Berrett-Koehler Publishers.

Tan, H. P., Plowman, D. \& Hancock, P. (2007). Intellectual capital and financial returns of companies. Journal of Intellectual Capital, 8(1), 76-95. DOI 10.1108/14691930710715079

Tandon, K., Purohit, H. \& Tandon, D. (2016). Measuring Intellectual Capital and Its Impact on Financial Performance: Empirical Evidence from CNX Nifty Companies. Global Business Review, 17(4) 980-997. DOI: 10.1177/0972150916645703

Teece, D. J. [ed.] (1987). The competitive challenge: strategies for industrial innovation and renewal. Cambridge, Mass.: Ballinger.

VanderKaay, S. (2000). Measuring the vital signs of intellectual capital. CMA Management, 74(4), 18-21.

Williams, M. S. (2001). Is intellectual capital performance and disclosure practices related? Journal of Intellectual Capital, 2(3), $192-203$

M. М. Салфей, Ph.D., Університет принца Саттама Бін Абдулазіза (Саудівська Аравія)

M. Наушад, Ph.D., Університет принца Саттама Бін Абдулазіза (Саудівська Аравія)

Місце інтелектуального капіталу в банківському секторі Саудівської Аравії.

Традиційно інтелектуальний капітал визначається як нематеріальні активи та права інтелектуальної власності (ПІВ) організацій. Авторами визначено, що інтелектуальний капітал також включає всі негрошові та нефрізичні ресурси, які повністю або частково контролюються організацією та сприяють створенню додаткової цінності. Інтелектуальні активи замінюють загальноприйняті фрактори виробництва, що пояснює необхідність розвитку інтелектуального капіталу як невід'ємного ресурсу. Ефективність використання якого впливає на рівень конкурентоспроможності підприємства. Так, дієвий механізм регулювання інтелектуального капіталу сприяє підвищенню вартості організації та сприяє досягненню визначених організаційних цілей. Система менеджменту інтелектуальним капіталом повинна враховувати нестабільність та невизначеність ринкових умов. Основною гіпотезою дослідження - наявність взаємозв'язку між рівнями ефективності управління інтелектуальним капіталом та конкурентоздатності у банківському секторі Саудівської Аравії. Інформаційною базою дослідження виступили офріційні дані та звіти про діяльність банків Садовської Аравії. Для перевірки висунутої гіпотези застосовано дві економетричні моделі, а саме: для оцінювання взаємозв'язку між рентабельністю капіталу (ROE) та рентабельністю активів банку (ROA), рівнем інтелектуального капіталу. При цьому авторами проаналізовано такі компоненти інтелектуального капіталу, як: ефективність використання людського капіталу (ЕЛК), Ефективність організаційного капіталу (ЕЗК) та Ефективність структурного капіталу (ЕСК). Емпіричні результати дослідження підтверджують наявність статистично значущого взаємозв'язку між ефективністю управління інтелектуальним капіталом у банку та рівнем його конкурентоздатності. Авторами визначено, що функціонування саудівських банків характеризується високою ефективністю, що пов'язано, у першу чергу, створенням необхідних умов для розвитку людського капіталу. У статті зазначено доцільність подальщих досліджень із метою порівняння рівня ефективності функціонування саудівських банків, ісламських та банків інших країн, де фрінансові операції здійснюються без врахування правил шаріату.

Ключові слова: інтелектуальний капітал, структурний капітал, банківський сектор, Саудівська Аравія.

Manuscript received: 30.05.2019.

(C) The author(s) 2019. This article is published with open access at Sumy State University. 